The Communications Web site, http://cacm.acm.org, features more than a dozen bloggers in the BLOG@CACM community. In each issue of Communications, we'll publish selected posts or excerpts.

\section{Bringing More Women, Immigrants, to Computer Science}

Gloria Townsend on encouraging women to pursue CS, and Sheldon Waite on supporting immigrants to fill STEM jobs.

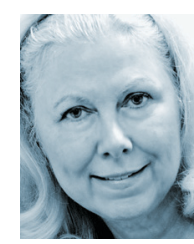

\section{Gloria Townsend Women Now Outnumber Men in Medical Schools. Computer Science Should Be Next.}

http://bit.ly/2PHmm80

April 26, 2019

In March we celebrated Women's History month, but there were few female computer scientists to celebrate. Women receive only $16 \%$ of U.S. bachelor's degrees in pure computer science (CS). In an age when women outnumber men in medical schools, we scratch our heads when we see such a small number. What's going on? The National Center for Women \& IT (NCWIT) reports: "By 2026, 3.5 million computingrelated job openings are expected. At the current rate, only $17 \%$ of these jobs could be filled by U.S. computing bachelor's degree recipients." More women graduating in CS will reduce the magnitude of the looming crisis.

ACM launched a pioneering effort to address plummeting graduation rates in the early 1990 s with the creation of a
Council on Women in Computing(ACMW). ACM-W seeks to recruit, retain, and celebrate women in computing.

I joined ACM-W in 2000, bringing with me a community-building idea for women in computing. In 1996, I used the fledgling Internet to count the numbers of female computer science majors in Indiana. Small pockets of women dotted the state. I dreamed of uniting these small groups of Indiana women by inviting them to attend a regional conference where each woman would find role models and a peer community. Attendees could build confidence by giving short "lightning talks" and poster presentations. The conference would dispel the myth of the lonely programmer hidden away in a cubicle by offering keynotes and panel presentations that share accurate career information. Women could find job and internship opportunities offered by industry and graduate school sponsors, who also serve as role models.

My colleagues and I organized the first conference, called an ACM Celebration, in Indiana in 2004. We imag- ined organizing Celebrations all over the world, so that no woman would feel isolated. Fast-forward 15 years, and ACM Celebrations now span the globe: Serbia, Chile, Ukraine, Canada, Philippines, Pakistan, Ireland, Turkey, Spain, and India, to name a few.

ACM-W Student Chapters sustain energy after one Celebration ends and before another begins. The ACM-sponsored organizations provide local activities on a smaller scale, but with the same Celebration mission to recruit, retain, and build community for women.

Beyond Celebrations and Chapters, what can institutions do? DePauw University awarded $47 \%$ of its computer science degrees to women in 2017-almost three times the national average. How? A lineup of traditional methods such as mentoring and role-modeling added new computer science majors, as did more specialized techniques like our CS Tryout. We invite every first-year woman (immediately before registration) to a preview of the introductory class, where third- and fourth-year female majors (and role models) sit alongside attendees to teach all that is needed to complete the first laboratory. The student teachers also talk briefly about their computing opportunities and career plans. Many women have zero computing experience, so the event removes the mystery surrounding computing classrooms and careers, as the older students describe their internship and research opportunities and their classroom projects-especially their impressive senior projects. 
Finally, what can individuals do? We underestimate the power of encouragement, in my opinion. Once I heard a young woman tell an audience, "I am a computer scientist today, because of three words that a professor wrote on my exam." In response to a recent post on my Facebook page, a woman wrote, "And here, just this past week, I once again happened upon my first CS1 exam upon which Gloria had written, 'CS Major????” (Ashley had saved the exam for 15 years). I encourage all of my talented students - both men and women. Woman after woman later tells me (as these two did) how my words influenced her. The number of men who have expressed the same sentiment? Zero!

This story is bittersweet. It's sad that women hunger for words of encouragement and value notes that take seconds to write. At the same time, this story about encouragement tells us how weas sisters, brothers, mothers, fathers, partners, teachers, and other mentorscan change girls' and women's lives.

An important time to encourage girls is in elementary school. These very young girls have as much interest in computing and technology as young boys do. There's no unimportant time to encourage, because girls begin to lose interest as they progress through middle school and high school. Support the many worthwhile programs that target girls and college women. Above all, use only supportive language when talking with girls and young women about computing.

\section{Sheldon Waite \\ Immigrants Help Solve the Looming STEM Worker Shortage}

http://bit.ly/2YOAPQh

April 12, 2019

As an engineering hardware manager working in the rapidly growing automotive electronics industry, I've been baffled by politicians who champion anti-immigration policies. If we want our economy to prosper, we should eagerly welcome the world-class talent that's knocking at our door.

I should know. I've witnessed firsthand the excellence newcomers bring to this country. About half of my 30person engineering team is comprised of foreign-born workers or children of recent immigrants. As a hiring manager, I have recruited the best, assem- bling a whip-smart, talented group that keeps us on the cutting edge of a highly competitive field.

Car companies like MercedesBenz and Ford hire us to make hightech accessories for their cars, such as screens, radios, embedded cellphones, and Wi-Fi devices. As connectivity devices become more integral to the car industry, demand for our work continues to rise. I have worked in this industry for more than 15 years and see how important diversity is to staying ahead of the competition. The type of work we do is highly technical, but also creative, because we are always trying to solve problems. That's why the diverse perspectives on my team are so critical to helping us find outof the-box solutions faster. Additionally, many of our bilingual employees give us a competitive advantage in the global economy. I'm proud to work alongside colleagues who work every day to make safer cars that improve consumers' lives.

I have heard people say they want to restrict immigration because they fear immigrants will take our jobs. But in my experience, there are not enough American-born workers to fill all these jobs. I just looked through a stack of résumés for summer internships, and the vast majority of applicants were immigrants or first- and second-generation Americans. This is emblematic of a broader trend: immigrants play a large role in science, technology, engineering, and math-or "STEM"-fields. In my home state of Illinois, for example, $24.1 \%$ of STEM workers were born in another country, according to a New American Economy analysis of various 2017 datasets (https://www.newamericaneconomy.org/locations/illinois/).

It is difficult to overstate this importance because employment in STEM jobs has grown significantly, exceeding overall job growth (https://pewrsr. ch/2UUpyPA). From 1990 to 2016, STEM occupations have grown $79 \%$, with computer jobs increasing 338\% over that same period, according to the Pew Research Center (https://pewrsr. $\mathrm{ch} / 2 \mathrm{vv} 5 \mathrm{gBN})$. These fields are expected to play a critical role in future U.S. economic growth.

In my state-Illinois-the labor market for tech talent is tighter than that on the coasts. That is why I support policies that help keep these skilled workers right here, where they can contribute to the workforce and the economy. In Illinois alone, immigrants contribute $\$ 17.6$ billion in taxes, include 118,055 entrepreneurs, and employ 390,685 people (http://bit.ly/2DJtvRr). Nationally, they pay $\$ 405.4$ billion in taxes, account for nearly 3.2 million entrepreneurs, and create approximately 8 million jobs (http://bit. ly/2vtCYb5). If our country's policies send the message "we don't want you here," then where will all this talent go? To foreign competitors.

I am lucky to have a team of talented engineers, but I know the tech industry as a whole struggles to find the skilled workers it needs. The recent spate of anti-immigration policies doesn't help their case. The H-1B visa program, which is the main way U.S. companies hire high-skilled foreign workers, is capped at 65,000 visas, plus an additional 20,000 visas for foreign applicants with a U.S. graduate degree (http://bit.ly/2VDzoK4). Demand for these workers in recent years far exceeds the available number of visas. Last year, nearly 200,000 people applied (http://bit.ly/2vyg5De), and for the past six consecutive years, the $\mathrm{H}-1 \mathrm{~B}$ visa cap has been reached within a week of the application period opening (http:// bit.ly/2PCMS3a). And existing $\mathrm{H}-1 \mathrm{~B}$ visa holders are grappling with the looming possibility the program allowing their spouses to work is on the chopping block (http://bit.ly/2J8teuO). This presents just another incentive to move to a country that is more inclusive.

Immigrants play a critical role in filling labor gaps; we should be embracing them. That means reversing policies that deter the hiring of foreignborn workers, creating a more streamlined immigration process, and cultivating a more supportive environment for newcomers.

Increasing immigration is the key to keeping our economy thriving. And the great thing about America is that people want to come here. So let's welcome them with open arms.

Gloria Townsend is a professor, and department chair of computer science, at DePauw University in Greencastle, IN, USA. Sheldon Waite is an engineering hardware manager in Chicago's Northwest suburbs.

(C) 2019 ACM 0001-0782/19/7 $\$ 15.00$ 